\title{
THE IMPROVEMENT OF MARRIAGE REGISTRATION SERVICES IN THE OFFICE OF RELIGIOUS AFFAIRS OF SAYUNG SUBDISTRICT TO PROVIDE SOCIAL WELFARE
}

\author{
Sri Wahyuningsih*
}

* Affiliation:

Department of English Language Education, Institut Agama Islam Negeri Kudus, Jl. Conge Ngembalrejo Bae Kotak Pos 51, Kudus, Indonesia

Wahyuningsih@ iainkudus.ac.id

\begin{abstract}
:
Along with the importance of the registration of marriage, the existence of Office of Religious Affairs is a part of a local government institution that is assigned to provide services to the community. In this matter, each state organizer has an obligation to provide excellent public services, meaning that the services provided by the government should be able to provide satisfaction to the community. This article aims at discussing some efforts to improve the service of marriage registration in the Office of Religious Affairs located in Sayung, Demak, Central Java. This research uses a descriptive qualitative method based on five service dimensions. The interview, observation and documentation are conducted to gather data. The result reveals that the quality of marriage registration service in the Office of Religious Affairs, Sayung has not been achieved ultimately. In fact, the Office of Religious Affairs, Sayung does not have a minimum service standard so that people cannot assess the service standard of marriage registration clearly. Therefore, in order to improve the service of marriage registration, the officers in the Office of Religious Affairs, Sayung need to improve the quality of marriage registration services that can be achieved by completing a clear minimum service standard.
\end{abstract}

Keywords: Office of Religious Affairs, Service, Marriage Registration

\section{INTRODUCTION}

In Indonesia, public administration is also known as the state administration which belongs to one aspect of government activities. The discussion of the concept of public administration according to Bailey in (Henry, 1989) must be directed at four types of theories, namely descriptive theory which deals with a description of hierarchical structure and a reciprocal relationship with the task environment, normative theory which deals with the purpose of values in the field - namely what public administration (practitioners) must b e done, alternative decisions are made and what policies must be studied and 
recommended by public administration experts to practitioners, assumptive theories which deals with rigorous understanding of personal or administrative realities that do not regard public bureaucrats as angels or demons and instrumental theories which deals with increased understanding managerial techniques for efficiency and effectiveness in achieving public goals.

The new paradigm of public administration causes a pattern of relations between the nation and society that emphasizes the interests of the community so that the nation is required to provide services to the better democratic community. This is in line with the statement of Denhardt \& Denhardt (2002, p. 27) advocating that the new paradigm of public service (new public service) is more directed at "Democracy, Pride and Citizen". Therefore, the values of democracy, citizenship and service for the public should be seen as fundamental norms in public administration. Thus, it can be concluded that the core or theoretical basis of the ideal public service according to the paradigm of the New Public Service is a public service that is responsive to various needs and values.

In conjunction with the porpose of public service, Sinambela (2010, p. 6) states that theoretically the purpose of public service is basically to satisfy the community. In order to achieve satisfaction, the quality service is demanded including transparent, accountable, conditional, participatory, equal rights, balanced rights and obligations, and services that consider aspects of justice. In accordance with public administration, At Thariq (2013) defines service is the quality of service for bureaucrats towards society. The word quality has many different definitions and varies from the conventional to the more strategic. Conventional definitions of quality usually describe the direct characteristics of a product, including performance, reliability, easy of use, aesthetics and so on.

In the scope of service, Barata in Mouw (2013) mentions that there are two types of service actors namely service providers and service recipients. A service provider is a party that can provide certain services to consumers, either in the form of services in the form of supply and delivery of goods or services. While service receivers are customers or consumers who receive services from service providers. In accordance with the quality of service, there are several factors that can affect the level of quality of public services. According to Moenir (2006), the supporting factors that can influence services include factors of awareness, regulatory, organizational, income, ability and skills and service facilities.

In addition, the factors that cause poor quality of service according to Tjiptono (2008, p. 98), include production and consumption that occur simultaneously, high labor intensity, inadequate support for internal customers, gap of communication, excessive expansion or development of services, short term business vision, short-term vision.

In accordance with the essence of public service, Holle (2011) asserts that public service includes improving the quality and productivity of the implementation of duties and functions of the government in the field of public services, encouraging efforts to better systems and service delivery so that public services can be more efficient and effective and supporting the growth of creativity, innovation and the participation of the community development and the welfare of the wider community. In conjunction with the quality of public services, Hariani, D. (2008) explains that the quality of public services provided by bureaucratic institutions of public services will be influenced by several factors including competency, quality of 
equipment used to services processes, bureaucratic culture, and so forth. Furthermore, Crosby in Yamit (2010) describes quality as zero defects, perfection and conformity to requirements. In this case, the competence of the bureaucratic members is an accumulation of a number of sub-variables such as education level, number of years of work experience and a number of trainings they have. Indeed, the procedure and output are merely influenced by the quality and quantity of equipment.

Gazperz, V. (1997, p. 2) explains that in order to create an effective customer-focused quality system, it is important to note several quality improvement dimensions. These dimensions or attributes that should be considered in improving service quality include timeliness of service, accuracy of service, politeness and friendliness in providing services, responsibility, completeness, namely concerning the scope of services and the availability of supporting facilities and other complementary services, ease of obtaining services, supporting facilities, personal services that are related to flexibility, handling special requests, location, service room, ease of access, vehicle parking, availability of information, instructions and other service supporting attributes.

Parasuraman et al (1985) previously develop a service measurement model through the service quality (SERVQUAL) approach which originally have ten determinants or dimensions of service quality, then finally they are summarized into five main determinants that determine service quality. Those are tangibleness reflects physical facilities and available equipments which deals with the ability of a company to show its existence to external parties, reliability which deals with the company's ability to provide services in accordance with the goals accurately and trustworthy, responsiveness which deals with the ability to assist and provide responsive and appropriate services to customers, assurance which consists of several components including credibility, security, competence and courtesy, and empathy which deals with the sincere attention and understanding of consumer needs.

Along with the importance of marriage registration, the existence of the office religious affairs is a part of the local government institution which is responsible of providing services to the community. As the core of the implementation of the government's general duties, especially in the field of Islamic religious affairs, it is expected to provide excellent service as indicated by the presence of good performance and capabilities of its officers accompanied by adequate facilities. The event of marriage is considerably very important and religious which is a legitimate relationship between a man and a woman for a long time. Therefore, each marriage is recorded according to the applicable regulations (article 2 paragraph 1 of the Marriage Law number 1 of 1974). For those who do marriage according to the Islamic religion, the recording is done at the Office of Religious Affairs, while for those who are Catholics, Christians, Buddhists, Hindus; the recording is done at the Civil Registry Office. Through the existence of marriage administration, the community has their rights, such as inheritance and livelihood for their children.

In relation to the importance of the Office of Religious Affairs in providing services to the community, it is expected that it has high integrity meaning that the leader and employees have a commitment to avoid corruption to create a better bureaucracy. In fact, it proves that the service integrity of the Office of Religious Affairs is still considered low. This is due to the 
existence of illegal levies or gratuities among the officers as experienced by Romli, the head of the Office of Religious Affairs of Kediri who received gratification in 2013. This causes a reaction from the head of the Indonesian government to take a position not to serve marriages outside working hours.

The case of gratification in the office of religious affairs may remind that the internal policy makers of the Ministry of Religion should revise the policy or rules of marriage services. As a result, the government finally issued PP No. 48 of 2014 as a substitute for PP No. 47 of 2004 and enacted it on July 10, 2014. In addition, PP No. 48 of 2014 describe that marriage at the office of religious affairs on working days and hours is free. On the other hand, those who get service of marriages administration conducted outside the office of religious affairs or outside working days and hours should pay 600,000 rupiahs. The Regulation Number 48 of 2014 has revised the cost of registering marriage (both at the office of religious affairs and outside) which was previously stipulated in PP Number 47 of 2004 amounting to 30,000 rupiah as state cash deposit of Ministry of Religion.

The office of religious affairs of Sayung is one of the providers of marriage registration services in Sayung Subdistrict covering twenty villages, namely: Banjarsari, Bedono, Bulusari, Dombo, Gemulak, Jetaksari, Kalisari, Karangasem, Loireng, Perampelan, Pilangsari, Purwosari, Sayung, Sidogemah, sidorejo, Sriwulan, Surodadi, Tambakroto, timbulsloko and Tugu. The large number of people married at the office of religious affairs of Sayung enhances the officers to improve the quality of marriage registration services. However, the quality of marriage registration services at the office of religious affairs of Sayung has not been maximally fulfilled. Indeed, there are several indicators that should be met. It can be seen from the absence of clear minimum service standards so that people cannot clearly understand the standard of marriage registration services.

In addition, there are a number of problems related to the dimensions of service quality "responsiveness", especially the late schedule for the implementation of marriage registration. It has been experienced by the bride and groom couples in Jetak sari village in December 2013. The wedding ceremony which was originally scheduled at 10 a.m. should delay 1.5 hours because the head of the office of religious affairs of Sayung had to give marriage servicess to ten bride and groom couples in different places at the same time. Therefore, it triggers anger from people in Jetak Sari village (Suara Merdeka, 2013, p. 1). Considering the case above, this article explores the efforts needed to improve marriage registration services in the office of religious affairs of Sayung Subdistrict.

\section{LITERATURE REVIEW Public Service}

According to Law Number 25 of 2009 in Article 1 point 1, public service is an activity or series of activities conducted to fulfill service needs in accordance with legislation for every citizen for service administration conducted by public service provider. In line with Law No. 25 of 2009, the notion of public services is also clarified in the Decree of the State Minister for the Empowerment of State Apparatus Number 63 of 2003 explaining that all forms of services carried out by Government Agencies at the Center, in Regions and within State-Owned 
Enterprises or Business Entities have Areas in the form of goods and or services, both in the context of efforts to fulfill community needs and in the implementation of statutory provisions.

The definitions above reveal that public services are all forms of public service activities carried out by central, regions government agencies, and the environment of State-Owned Enterprises (BUMN) and Regional Government-Owned Enterprises (BUMD) in the form of goods and services efforts to meet the needs of the community in the context of implementing

statutory provisions. In conjunction with it, in order to meet the community needs, the government has an obligation to provide the best service to the community. In terms of service, the government does not see the status of society and there is no any discrimination. Further, the service is conducted on time.

In addition, in this era of regional autonomy, the demands of the effective and efficient public services from government employees are highly needed. This is in accordance with Sinambela (2010, p. 3) describing that basically every human being needs service, even in extreme terms it can be said that service cannot be separated from human life. In this case, the community as the subject of service do not like convoluted services and have risk due to a long chain of bureaucracy. In providing public services, the government should pay attention or consider the nature of the public service itself. The essence of public service according to Holle (2011) includes improving the quality and productivity of the implementation of duties and functions of the government in the field of public services, encouraging efforts to streamline systems and service delivery so that public services can be more efficient and effective and encouraging the growth of creativity, initiative and the participation of the community to improve the welfare of the wider community.

Considering this, in order to realize equitable national development, the government and the community should have cooperation which can be achieved through public services. Further, community as the main actor of development and the government is obliged to direct, foster and create a conducive environment to support the activities of people. Moreover, activities between the community and the government should support each other in a unified step to achieve a national development goal of a nation.

\section{Quality of Public Services}

Quality is an important aspect in determining the success of an institution or agency. If an institution has been able to provide or provide quality services, the institution has strengthened one of the foundations for creating customer satisfaction. Goetsh and Davis in Arif (2007) suggest that quality is a dynamic condition that relates to products, services, people, processes and environments that meet or exceed expectations. In line with Goetsh and Davis, Crosby in Yamit (2010) describes quality as zero defects, perfection and conformity to requirements. Based on this definition, it can be deduced that quality is a basic condition related to products, services, people, processes and the environment in meeting expectations in accordance with products, services, people, processes and environment according to existing specifications depending on ability to generate customer satisfaction.

Sinambela $(2010$, p. 6) states that theoretically the purpose of public service is basically to satisfy the community. In order to achieve satisfaction, the quality service is demanded 
including transparent, accountable, conditional, participatory, equal rights, balanced rights and obligations, and services that consider aspects of justice. In accordance with public administration, At Thariq (2013) defines service is the quality of service for bureaucrats towards society. The word quality has many different definitions and varies from the conventional to the more strategic. Conventional definitions of quality usually describe the direct characteristics of a product, including performance, reliability, easy of use, aesthetics and so on.

In the scope of service, Barata in Mouw (2013) mentions that there are two types of service actors namely service providers and service recipients. A service provider is a party that can provide certain services to consumers, either in the form of services in the form of supply and delivery of goods or services. While service receivers are customers or consumers who receive services from service providers. In accordance with the quality of service, there are several factors that can affect the level of quality of public services. According to Moenir (2006), the supporting factors that can influence services include factors of awareness, regulatory, organizational, income, ability and skills and service facilities.

In addition, the factors that cause poor quality of service according to Tjiptono (2008, p. 98), include production and consumption that occur simultaneously, high labor intensity, inadequate support for internal customers, gap of communication, excessive expansion or development of services, short term business vision, short-term vision. Furthermore, Hariani (2008) explains that the quality of public services provided by bureaucratic institutions that administer public services influenced by several factors including apparatus competency, the quality of equipment used to process types of services, bureaucratic culture, and so on. In this case, the competence of the bureaucratic apparatus is an accumulation of a number of sub-variables such as education level, number of years of work experience; variations in training that have been received. Meanwhile, the procedure and output are influenced by the quality and quantity of the used equipment.

Based on the description above, it can be seen that a number of efforts to improve the quality of services, companies or agencies should increase the commitment and awareness, ability and productivity of workers, especially for those who deal directly with consumers. Furthermore, it can be deduced that if the system and quality techniques are good but the people who implement (workers) and the tools used are not well, then the expected quality of service will not be realized. In addition, the quality is not only evaluated by products or results, but also the processes, environment and human resources.

Gazperz, V. (1997, p. 2) explains that in order to create an effective customer-focused quality system, it is important to note several quality improvement dimensions. These dimensions or attributes that should be considered in improving service quality include timeliness of service, accuracy of service, politeness and friendliness in providing services, responsibility, completeness, namely concerning the scope of services and the availability of supporting facilities and other complementary services, ease of obtaining services, supporting facilities, personal services that are related to flexibility, handling special requests, location, service room, ease of access, vehicle parking, availability of information, instructions and other service supporting attributes.

The dimensions above are considerably crucial to note in order to realize excellent service quality. Besides Gazpers, other marketing experts such as Parasuraman et al (1985) 
first develop a service measurement model through a service quality (SERVQUAL) approach which originally have ten determinants or dimensions of service quality, then summarized into five main determinants determining service quality. These include tangibleness wihich reflects available physical facilities and equipment, namely the ability of a company to show its existence to external parties, reliability which deals with the company's ability to provide services in accordance with the promised accurately and confidently, responsiveness which deals with the ability to help and provide services that are responsive and appropriate to customers with the delivery of clear information, assurance which consists of several components including credibility, security, competence and courtesy, empathy which deals with individual or personal attention given to customers by trying to understand the desires of consumers.

In order to increase the quality of services, the significant ways of improvement are needed so that the benefits can be seen for the community. Thus, the users of public organization services namely the community can receive services according to their needs, more relevant and effective. Furthermore, the efforts to improve the quality of public services can be done by improving management of service quality, namely the effort to reduce the gap between the level of service provided by the organization with the expectations and desires of the user community. In this case, management should be able to apply management techniques and strategies that are oriented to the needs of the community.

In addition, performance measurements are very necessary in order to identify the level of inequality. Furthermore, performance monitoring needs to be carried out as an evaluation tool for public services and public service provider organization programs that are in accordance with the needs of the society. This monitoring can also be used to identify whether the level of quality of public services is better than before. A number of crucial steps in monitoring the performance of public service organizations include developing performance indicators that describe the achievement of organizational goals, describing the results of achievement of goals and programs based on performance indicators and identifying whether the organization has carried out activities effectively and efficiently as a basis for improving the quality of services to the community.

In relation to the quality of public services, it can be concluded that government organizations need to consider supporting factors that can be used as tools to improve and strengthen service quality and inhibiting factors as challenges or obstacles. This is in line with the theory of "The triangle of balance in service quality" advocated by Morgan and Murgstroyd cited in Warella (1997, p. 20) describing that in order to actualize maximum service quality, the balance of the three components which includes interpersonal component, procedure environment (procedure / system), and professional / technical component (facilities and infrastructure) should be well considered.

\section{METHOD}

This study anchors a qualitative research method with an approach of descriptive analysis. In order to obtain data, the writer determines the informants consisting of the head of the office of religious affairs of Sayung, the staffs, and several people who have done marriage registration at the office of religious affairs of Sayung. They come from the villages of 
Prampelan, Karangasem and Bulusari as representatives of the villages in Sayung Subdistrict having a large population. In addition, to collect data, observation, interview, and documentation are conducted. After the data is collected, the data analysis is done by using an interactive model of qualitative data analysis methods which include data collection, data reduction, data presentation, and conclusion drawing.

\section{RESULT}

Strategies to Improve Marriage Registration Services at The Office of Religous Affairs of Sayung The office of religious affairs of Sayung is a service provider having work areas of twenty villages, namely: Banjarsari, Bedono, Bulusari, Dombo, Gemulak, Jetaksari, Kalisari, Karangasem, Loireng, Perampelan, Pilangsari, Purwosari, Sayung, Sidogemah, sidorejo, Sriwulan, Surodadi, Tambakroto, timbulsloko and Tugu. The large number of villages of Sayung Subdistrict makes the people who use marriage registration services at the office of religious affairs of Sayung rank number three in Demak Regency. Therefore, in order to provide maximum services to the community, the office of religious affairs of Sayung is considered to make efforts to improve the quality of marriage registration services from the aspect of reliability, responsiveness, assurance, empathy and tangible. These efforts include increasing the number of headmen in order to enhance the marriage service at the office of religious affairs of Sayung, encouraging the staffs of the office of religious affairs to master the skill of technology, improving Facilities and Infrastructure, improving the performance by completing clear minimum standards of Marriage Administration Service and improving the performance by completing clear minimum standards of Marriage Administration Service.

\section{DISCUSSION}

\section{Increasing the number of headmen in order to enhance the marriage service at the office of religious affairs of Sayung}

Every service user wants to get immediate and appropriate service from the office of religious affairs. In order to know it in detail, an interview to several informants from the office of religious affairs as a service provider and the community as service users was conducted. It has been described by Khariroh, the bride from Bulusari village:

"When I get the marriage administration service at the office of religious affairs of Sayung, I have to wait for half an hour to get the marriage service. It is caused by the large number of several wedding couples who get the marriage administration service from other villages at the same time" (Khariroh, 5 December 2015).

The statement above is in line with Khanifah, the bride from Prampelan village:

"In my opinion, the process of marriage administration service takes a long time, that is not immediately. I have to wait in line for other brides who are undergoing a marriage check. This is because there are limited number of staffs at the office of religious affairs while there are many people who use marriage services. Therefore, people have to wait for a long time " (Khanifah, December 4, 2015). 
The description above indicates that most people argue that the ability of staffs at the office of religious affairs of Sayung in providing services appropriately has not been fulfilled well. This is strengthened by Lutfi Hanif, the headman of the office of religious affairs of Sayung.

"If there are no obstacles, we will immediately serve the community. In fact, there are concurrent matters; the public must queue up to wait for other brides during the marriage registration process. This is because there are only two headmen in this office (Headman, December 4, 2015).

The description above is supported by Muntasirun, the head of the office of religious affairs of Sayung:

"We have tried not to delay service. However, the limited number of employees at the office of religious affairs of Sayung makes it people should wait for other brides in the process of registering marriage administration" (Head of the office of religious affairs of Sayung, 4 December 2015).

According to Wahyuningsih (2016), Sayung Subdistrict is one of the areas in Demak that is densely populated which occupies the number three population after Mranggen and Demak cities in Demak district. This has implications for the number of marriage events which range from 1070 to 1200 each year. Regarding the number of marriages, the ideal number of heads at the office of religious affairs of Sayung District should be more than two headmen. In fact, there are only two headmen at the office of religious affairs of Sayung.

The lack of the number of headmen and staff at the office of religious affairs is very influential on its performance to carry out basic tasks, causing the process of marriage services is less optimal. This is because in one day there are ten or more marriages in different places or villages at the same time. As a result, the headman feels overwhelmed in serving the marriage administration. By adding the number of headmen, it is expected that the office of religious affairs of Sayung can serve marriage registration in a appropriate manner so that the community is served maximally.

\section{Encouraging the staffs of the office of religious affairs to master the skill of technology}

Some staffs at the office of religious affairs of Sayung seem not have the expertise and skills especially technology such as internet applications. In fact, only a few of them are proficient in technology, while others cannot. This is in accordance with the statement of the headman of the office of religious affairs of Sayung District:

"The staffs of the office of religious affairs of Sayung are able to use assistive devices such as computers and printers to check the bride's data. However, for certain programs or certain applications, only a few of them who master technology "(Headman, 4 December 2015) 
Therefore, it is expected that all staffs at the office of religious affairs of Sayung possess skills or expertise in the field of IT concerning with the application or system of marriage registration services to make it easier for the service provider and the community in terms of marriage registration services.

\section{Improving Facilities and Infrastructure}

In service processes, physical facilities or supporting facilities are an inseparable part in serving the community. Without supporting facilities, the process of recording marriage services will be hampered. In order to find out the quantity of physical facilities at the office of religious affairs of Sayung, the interview was conducted. It has been described by Rokhimah, the bride from Karang Asem village:

«In my opinion the quantity of physical facilities at the office of religious affairs of Sayung is still inadequate and it needs to be improved for convenience. It can be seen from the building which is not too big. In addition, the wedding room and the living room are narrow «. (Rokhimah, 29 November 2015)

It is in line with Faik, the bride from the village of Prampelan:

"The quantity of physical facilities at the office of religious affairs of Sayung is inadequate, for example the place of the marriage looks simple. It is only decorated by perfunctory decorations. Therefore, I decided to get married at home. In addition, the highway area of Sayung is quite heavy and it tends to a traffic jam. Therefore, I feel uncomfortable " (Faik, 29 November 2015).

The data from the interview above shows that some people describes that the quantity of physical facilities at the office of religious affairs of Sayung is still inadequate. As a result, they feel uncomfortable if they marry at the office of religious affairs of Sayung. In addition, people feel more c omfortable if they marry outside the office of religious affair. With this regard, they will be more comfortable if they do it at home. This is strengthened by Muntasirun, the head of the office of religious affairs of Sayung:

"In my opinion, the quantity of physical facilities at KUA is indeed inadequate. The KUA building is also not too big, the work / service room is still mixed, the room has not been air conditioned. Therefore, physical facilities need to be improved" (Head of the office of religious affairs of sayung, 4 December 2015).

It is in line with Hanif, the headman of the office of religious affairs of Sayung:

"The quantity of physical facilities at KUA is indeed inadequate and still needs to be improved. For example, the area of the office of religious affairs of Sayung is not too wide and it has not met the building area. The rooms are small and a work space has not been air conditioned" (Hanif, December 4, 2015).

Based on the res ult of interviews fr om both the community and the officials of the office of religious affairs, it can be seen that the quantity of physical facilities at the office of religious affairs of Sayung is inadequate. In this matter, there are a number of facilities such as 
the workspace and parking area that need to be repaired. This is also supported by the results of observations of the writer at the office of religious affairs of Sayung which has been proved by the following documentation:

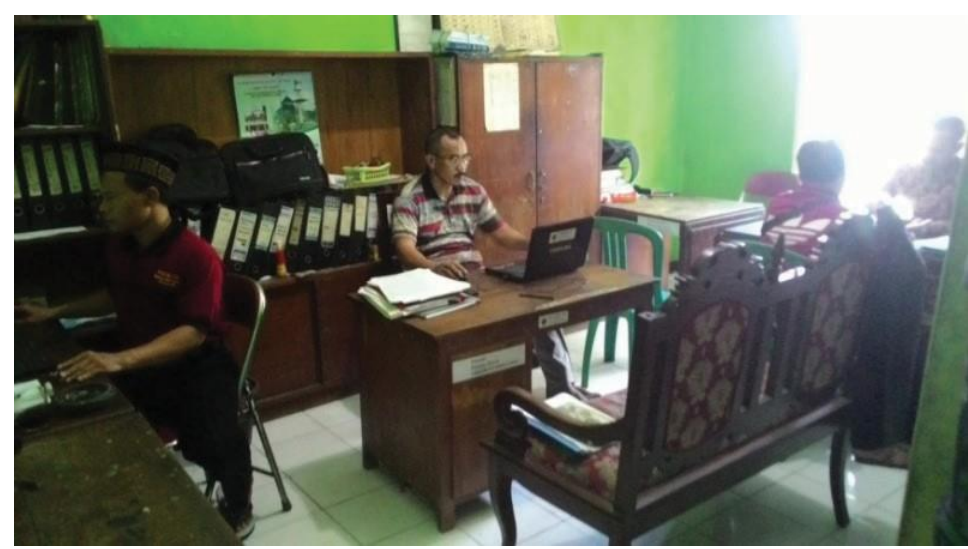

Figure 1. The rooms are small and narrow

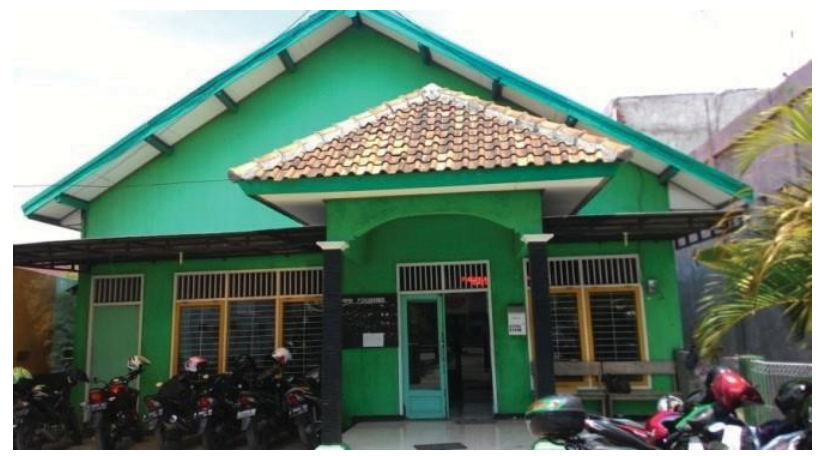

Figure 2. The Building of the Office of Religious Affairs of Sayung

Facilities and infrastructure are one of the important aspects in the field of public services. In order create the comfortable service to the community, the officials of the office of religious affairs of Sayung should renovate the room, for instance, the waiting room or living room should be expanded, the parking lot is needed to be expanded, and the marriage room is recommended to be neatly designed so that it looks eye-catching.

\section{Improving the performance by completing clear minimum standards of Marriage Administration Service}

Every place of public service should have a minimum service standard (SPM) as a guarantee of providing quality services to service users. This minimum service standard is usually in the form of job descriptions of staffs of the office of religious affairs of Sayung who are usually posted around the location. With regard to this, the minimum service standards in the office of religious affairs of Sayung sub-district can be seen from the community who get marriage services at the office of religious affairs of Sayung. It has been revealed by the bride from Karang Asem village as follows: 
"In my opinion, the service standard at the office of religious service is not clear. Even though, it was written the cost of marriage administration at the office of religious affair of Sayung is free and the cost of marriage at home is 850,000 rupiahs. In fact, I paid 900,000 rupiahs when I married at home through modin services" (Eva, November 29, 2015).

It is in line with the bride from the Prampelan village:

"In my opinion the minimum service standard at KUA Sayung is not very clear because there is no the minimum service standard so that I do not know anything about the job description of marriage registration. (Nur Khanifah, December 4, 2015).

The results of interviews with the community indicate that the office of religious affair of Sayung does not have a clear minimum service standard. This is also strengthened by the results of interviews with the office of religious affair of Sayung. It has been explained by Asnawi, the secretary of the office of religious affair of Sayung:

"Actually, the rules regarding the cost of marriage already exist in the office of religious affairs. Getting married in the office is free of charge while getting married outside the office of religious affairs is charged 600,000 rupiahs and it is directly deposited into the state treasury. If there are people who pay above 600,000 rupiahs, it is not our responsibility. It may be given to modin. There is no any minimum service standard in office of religious affair" (Asnawi, 4 December 2015).

In order to maximize the quality of public services, each service provider including the office of religious affair Sayung should have the minimum service standards. It should be provided by the local and public government. In fact, the office of religious affair of Sayung is a service provider that does not have the minimum service standard so that the community or service users are not able to know the standard of service of marriage administration. Therefore, to improve the quality of services including marriage registration, the office of religious affair of Sayung should improve the performance by making or completing a minimum service standard clearly and displaying it at the office so that people can read and know the standard of marriage registration services clearly. In addition, the minimum quality of a public service can be accessed by people living in Sayung Subdistrict.

Socializing to people about the existence of application service of a marriage management information system

KUA Sayung has a marriage management information system application. This can be accessed via the internet so that people can check marriage information through the application program. Further, they do not have to go back to the office of religious affairs of Sayung to find out the schedule of marriage administration. Unfortunately, the application has not been utilized optimally since most people do not know the application and they rarely access the internet. Considering this, the office of religious affairs of sayung should disseminate to the community of Sayung sub-district about the use of the marriage management information system application so that they can use it easily. This can be proved by the following documentation: 


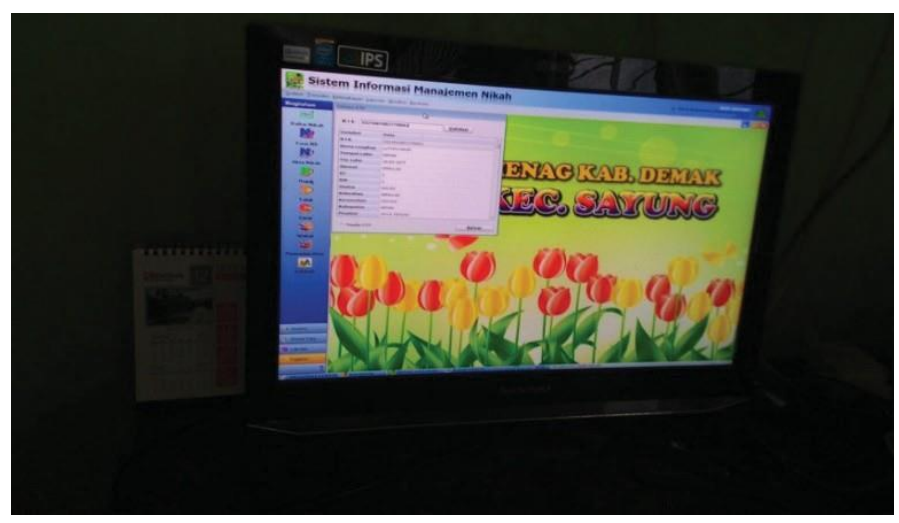

Figure 3. Marriage Management Information System

\section{CONCLUSION}

Service quality is a major priority for service providers. The office of religious affairs of Sayung is one of the providers of marriage registration services in Sayung Sub-district having a working area covering twenty villages. In order to improve the quality of marriage registration services, the office of religious affairs of Sayung is expected to have some efforts by having the number of headmen so that the marriage services at office of religious affairs of Sayung are not hampered, the staffs of office of religious affairs of Sayung should better master the skills in technology, providing better the facilities and infrastructure, improving performance by completing a clear minimum service standard and socializing to people about the existence of a marriage management information system application so that they know the schedule of marriage easily.

\section{REFERENCE}

Arief (2007). Pemasaran Jasa \& Kualitas Pelayanan. Malang: Bayu Media Publishing.

At Thariq, A. N. (2013). Kualitas Pelayanan Publik di Dinas Kependudukan dan Catatan Sipil Kabupaten Malinau (Studi Implementasi Pelayanan Administrasi Kependudukan). eJournal Pemerintahan Integratif, 1 (3), 331-345.

Denhardt, J. et al. (2002). The New Public Service :New York. ME Sharpe Inc

Gasperz, V. (1997). Manajemen Kualitas Dalam Industri Jasa, Jakarta: PT Gramedia Pustaka

Holle, E. (2011). Pelayanan Publik Melalui Electronic Government: Upaya Meminimalisir Praktek Mal Administrasi dalam Meningkatkan Public Service. Jurnal Sasi, 17 (3), 21-30

Hariani, D. (2008). Manajemen Komplain dan Penanganan Keluhan dalam Pelayanan Publik. Dialogue Jurnal Ilmu Administrasi dan kebijakan Publik.

Henry, N. (1989). Public Administration and Public Affairs, fouth edition, Prentice Hall, Englewood Cliffs, New Jersey.

Mouw, E. (2013). Kualitas Pelayan Publik di Daerah Sebuah Kajian Teoritis. Jurnal UNIERA, $2(2), 92-103$ 
Moenir, H A S. (2006). Manajemen Pelayanan Umum di Indonesia. Jakarta: Bumi Aksara

Osborne, D. \& Peter. (2000). Memangkas Birokrasi, Lima Srategi Menuju Pemerintahan Wirausaha. Jakarta : Victory Jaya Abadi.

Parasuraman, A., et al. (1985), “A conceptual model of service quality and its implications for future research", Journal of Marketing, 49 (4), 41-50

Sinambela, L. (2010). Reformasi Pelayanan Publik. Jakarta: Bumi Aksara.

Suara Merdeka. Hampir Dikeroyok. Retrived on 15 Mey 2017 from: http://epaper.suaramerdeka. com/read/2013/12/21/11SM21L13NAS.pdf

Tjiptono. (2008). Service Management Mewujudkan Layanan Prima. Yogyakarta: Andi

Warella, Y., (1997). Administrasi Negara dan Kualitas Pelayanan Publik, Naskah Pidato Pengukuhan Guru Besar FISIP UNDIP Semarang.

Wahyuningsih, S. (2016). Analisis Kualitas Pelayanan Pencatatan Nikah pada KUA Kecamatan Sayung Kabupaten Demak. Tesis UNDIP Semarang.

Yamit, Z. (2010). Manajemen Kualitas Produk \& Jasa. Cetakan ke-5. Yogyakarta: Ekonisia.

Undang-Undang Nomor 25 tahun 2009

\section{ACKNOWLEDGEMENT}

I am grateful to each of the Head and staff of the Office of Religious Affairs of Sayung with whom I have had the pleasure to do a research. They have provided me guidance and insights about the service of marriage administration at the Office of Religious Affairs. 